\title{
A beacon for the COVID-19 epidemic control in Brasil: seroepidemiological population-based surveys
}

\author{
Maria Rita Donalisio ${ }^{1 *}$ (1)
}

The novel severe acute respiratory syndrome coronavirus 2 (SARS-CoV-2), which was firstly identified in late December 2019 in China, has spread rapidly worldwide. However, epidemics are expressed from different forms around the world. The epidemic curves do not follow a "natural path" due to different social, epidemiological, and cultural contexts, access to health services and to diagnostic tests, vaccine, and preventive measures in different regions ${ }^{1}$. Oliveira et al. ${ }^{2}$ investigated disparities in the clinical profile of coronavirus disease (COVID19) and in the groups that can be more affected by the disease in Brasil, China and Italy since the pandemic beginning. In Brasil, the authors reported the highest percentage of cases among individuals aged $<60$, male, and diabetes-affected ones ${ }^{2}$.

Despite efforts put to maintain social distancing, the lack of effective drugs and of a vaccine for COVID-19 have led to an increase in the disease incidence in various parts of Brasil ${ }^{3}$. However, there is limited information available on the epidemic and its indicators in the country due to the scarcity of diagnostic tests and to the large proportion of mild and asymptomatic cases. In addition, there is a lack of parameters and information concerning the disease transmission in different regional contexts. Most studies conducted in the first few months of the COVID-19 pandemic were focused on symptomatic patients with severe manifestations of the disease or in its acute stages. Also, they were obtained in one-off testing, in convenience tests in high-risk populations, or in health professionals ${ }^{4-6}$.

Population-based epidemiological surveys are an interesting strategy to address the lack of indicators for the COVID-19 epidemic and may answer relevant questions to better understand its dynamics ${ }^{7}$. They provide information regarding the extent of viral circulation and dissemination of the disease ( $R$ effective), thereby allowing more robust estimates of lethality rates and providing parameters for prediction models in different transmission scenarios ${ }^{8}$. Estimates of the actual prevalence of infection in the population are useful for assessing the impact of public health interventions and can be used in clinical vaccine trials.

Population-based surveys have guided public health measures in several countries. Cross-sectional studies in Spain have shown the most affected regions around Madrid and the disease transmission? . Furthermore, various authors in Iceland have identified populations at $\operatorname{risk}^{10}$. A study conducted in Gangelt, Heinsberg district, in Germany, where the first case of COVID-19 was announced in the country, reported that $15 \%$ of the city population presented antibodies against SARS$\mathrm{CoV}-2$. The first surveys carried out in the United States, in Santa Clara and in Los Angeles, California, anticipated the concern of viral spread ${ }^{11,12}$.

Surveys have also been conducted in Brasil, some of which were restricted ones, and others had a greater scope $\mathrm{e}^{13-18}$. Among the population-based investigations for COVID-19 undertaken globally that had a greater coverage, the seroepidemiological survey performed every two to three weeks in Brasil stands out, which was organized by Universidade Federal de Pelotas $^{15}$. Random population samples in 133 cities that are commercial and economic hubs in 27 states from five regions of Brasil were investigated and underwent immunochromatographic testing for the detection of $\operatorname{IgM} / \mathrm{IgG}$ antibodies, using the lateral flow assay. In May of 2020, the results revealed a great variability in the prevalence of antibodies against SARSCoV-2 in the country, from $>1 \%$ in cities in the South and Southeast region to $20-25 \%$ in the North. Additionally, a high prevalence rate $(>10 \%)$ was reported in cities on the Amazon River banks in the first two survey stages. This extensive field effort led to around 30.000 collections at each survey stage. The first results showed a high rate of transmission growth (53\% every three weeks) and revealed that there were around seven unknown cases for every reported case. Another intriguing

\footnotetext{
'Universidade Estadual de Campinas, Faculdade de Ciências Médicas - Campinas (SP), Brasil.

*Corresponding author: rita.donalisio@gmail.com

Conflicts of interest: the authors declare there is no conflicts of interest. Funding: none.

Received on August 24, 2020. Accepted on August 27, 2020.
} 
result under investigation suggests that the indigenous people in the country has greater susceptibility $(3.7 \%)$ than the white population $(0.6 \%)$ of the Northern region. A mosaic of epidemics with different speeds and impacts needs to be analyzed in various ways, requiring specific actions from control and surveillance agencies.

Other basic surveys in Brasil have disseminated markers of epidemics at the local level, with strategic information to adjust control measures. In Ribeirão Preto, São Paulo State, the seroprevalence was $1.2 \%$ in the first week of May of 2020, revealing low viral circulation ${ }^{14}$. In Campinas, also in the State of São Paulo, it was $2.2 \%$ based on the results of the first testing conducted in June of 2020 . This prevalence, then, increased to $3.7 \%$ in July of 2020, with a higher rate among the poor population of Campinas, as disclosed by the Municipal Health Department (MHS, acronym in Portuguese) ${ }^{19}$. In a study focused on the prevalence of antibodies in a population sample from six districts in the city of São Paulo, in which three districts were the most affected, among individuals aged $>18$, the rate was $5.4 \%$, thus revealing that the actual number of individuals infected was 10 times greater than that notified by the epidemiological surveillance from May of $2020^{16}$. Several stages of the survey in Sáo Paulo in 2020, released by the MHS, revealed the seroprevalence to be $11.1 \%$, in June, reaching $15.6 \%$ in December, with increased positivity in the elderly and poor individuals, indicating social inequality.

Results of school surveys performed from August of 2020 that were reported in the media led to the modification of the MHS guidelines, which postponed the opening of face-to-face classes in São Paulo. In April, in the state of Rio Grande do Sul, serial surveys in nine sentinel cities revealed that the epidemic was in the early stage, although it was on the rise ${ }^{13}$. In the
Espírito Santo state in the last week of May of 2020, serological survey in 19 towns identified that $5.1 \%$ of the Capixaba population had antibodies against SARS-CoV-2; 70\% of the population included black and brown individuals. Serial serological surveys in representative samples of the population of Teresina, in Piauí State, showed transmission growth from April to May ${ }^{17}$. In Maranhão State, Silva et al. showed prevalence rates of around $40 \%$ between July and August of $2020^{18}$.

These results highlight the importance of learning about the parameters of epidemics on population bases, particularly in serial stages that reveal transmission trends, the groups mostly affected by the epidemic and those with small exposure to the disease, helping to guide the control measures. Thus, this strategy in cities or micro regions can be supported by State Health Departments and the Brazilian Department of Health for the systematic monitoring of the epidemic and its phases. It can also guide interventions at the local or regional levels, thus supporting decisions concerning the relaxation of social distancing and identifying individuals that could return to work or school.

Some limitations of these initiatives are the variable accuracy and heterogeneity of the available serological test ${ }^{20}$. It is worth highlighting the controversies regarding the performance and duration of these antibodies during the immune response, considering that the serological tests do not identify neutralizing antibodies against SARS-CoV-2, generating debates regarding the duration of immune response and other factors that modulate herd immunity ${ }^{7}$.

In conclusion, there are many questions regarding the epidemic that need to be clarified. However, population-based surveys indirectly monitor the viral circulation in the community and act as a beacon for public health, shedding light on disease transmission in specific regions, helping to adjust measures accordingly.

\section{REFERENCES}

1. World Health Organization [Internet]. Coronavirus Disease. Situation Report 146. 2020 [cited on Jun 14, 2020]. Available from: https://www.who.int/docs/default-source/ coronaviruse/situation-reports/20200614-covid-19-sitrep-146. pdf?sfvrsn=5b89bdad_6

2. Oliveira MHS, Wong J, Lippi G, Henry BM. Analysis of clinical and demographic heterogeneity of patients dying from COVID-19 in Brazil versus China and Italy. Braz J Infect Dis. 2020;24(3):273-5. https://doi.org/10.1016/j.bjid.2020.05.002

3. Codeço C, Villela D, Coelho FC, Bastos LS, Carvalho LM, Gomes MFC, et al. Estimativa de risco de espalhamento da COVID-19 no Brasil e avaliação da vulnerabilidade socioeconômica nas microrregiões brasileiras [Internet]. Rio de Janeiro: FIOCRUZ/ PROCC. 2020 [cited on May 10, 2020]. Available from: https:// www.arca.fiocruz.br/handle/icict/40509.
4. Adams JG, Walls RM. Supporting the health care workforce during the COVID-19 global epidemic. JAMA. 2020;323(15):1439-40. https://doi.org/10.1001/jama.2020.3972

5. Randhawa AK, Fisher LH, Greninger AL, Li SS, Andriesen J, Corey, L, et al. Changes in SARS-CoV-2 positivity rate in outpatients in Seattle and Washington state. JAMA. 2020;323(22):2334-6. https://doi.org/10.1001/ jama.2020.8097

6. Ministério da Saúde. Secretaria de Ciência, Tecnologia, Inovação e Insumos Estratégicos em Saúde - SCTIE. Covid19: diretrizes para diagnóstico e tratamento de pacientes [Internet]. Brasília: Ministério da Saúde. 2020 [cited on June 11, 2020]. Available from: https://saude.rs.gov. br/upload/arquivos/202004/14140600-2-ms-diretrizescovid-v2-9-4.pdf 
7. Altmann DM, Douek DC, Boyton RJ. What policy makers need to know about COVID-19 protective immunity. Lancet. 2020;395(10236):1527-9. https://doi.org/10.1016/S01406736(20)30985-5

8. World Health Organization. Population-based age-stratified seroepidemiological investigation protocol for coronavirus 2019 (COVID-19) infection [Internet]. 2020 [cited on Jun 11, 2020]. Available from: https://apps.who.int/iris/bitstream/ handle/10665/332188/WHO-2019-nCoV-Seroepidemiology2020.2-eng.pdf

9. Pollán M, Pérez-Gómez B, Pastor-Barriuso R, Oteo J, Hernán $M A$, Pérez-Olmeda $M$, et al. Prevalence of SARS-CoV-2 in Spain (ENE-COVID): a nationwide, population-based seroepidemiological study. Lancet. 2020;396(10250):535-44. https://doi.org/10.1016/S0140-6736(20)31483-5

10. Gudbjartsson DF, Helgason A, Jonsson H, Magnusson OT, Melsted P, Norddahl GL, et al. Spread of SARS-CoV-2 in the Icelandic population. N Engl J Med. 2020;382:2302-15. https:// doi.org/10.1056/NEJMoa2006100

11. Bendavid E, Mulaney B, Sood N, Shah S, Ling E, BromleyDulfano R, et al. COVID-19 antibody seroprevalence in Santa Clara County, California. Int J Epidemiol. 2021;22:dyab010. https://doi.org/10.1093/ije/dyab010

12. Sood N, Simon P, Ebner P, Eichner D, Reynolds J, Bendavid E, et al. Seroprevalence of SARS-CoV-2-Specific antibodies among adults in Los Angeles County, California. JAMA. 2020;323(23):242527. https://doi.org/10.1001/jama.2020.8279 2020

13. Silveira MF, Barros AJD, Horta BL, Pellanda LC, Victora GD, Dellagostin OA, et al. Population-based surveys of antibodies against SARS-CoV-2 in Southern Brazil. Nat Med. 2020;26(8):1196-9. https://doi.org/10.1038/s41591020-0992-3.
14. Comitê Técnico do Inquérito Epidemiológico SARS-CoV-2. Avaliação da prevalência de marcadores virológicos e sorológicos do SARS-CoV-2 na população de Ribeirão Preto: um inquérito epidemiológico [Internet]. 2020 [cited on May 30, 2020]. Available from: https://wnww.apcdrp. com.br/arquivos/paginas/uploads/Relatario_Final_do_Inquerito.pdf

15. Hallal PC, Hartwig FP, Horta BL Silveira MF, Struchiner CJ, Vidaleti LP, et al. SARS-CoV-2 antibody prevalence in Brazil: results from two successive nationwide serological household surveys. Lancet Glob Health. 2020;8(11):e1390-8. https://doi. org/10.1016/S2214-109X(20)30387-9

16. Grupo de Mapeamento SARS-CoV-2. Inquérito domiciliar para estimar a soroprevalência da infecção por SARS-CoV-2 no município de São Paulo [Internet]. 2020 [cited on Aug 01, 2020]. Available from: https://covidrn.lais.ufrn.br/wp-content/uploads/2020/05/ final-resultados-inqu\%C3\%A9rito-amostral.pdf

17. Vieira MADCES, Vieira CPB, Borba AS, Melo MCC, Oliveira MS, Melo RM, et al. Sequential serological surveys in the early stages of the coronavirus disease epidemic: limitations and perspectives. Rev Soc Bras Med Trop. 2020;53:e20200351. https://doi.org/10.1590/0037-8682-0351-2020

18. Silva AAM, Lima-Neto LG, Azevedo CMPS, Costa LMM, Bragança MLBM, Barros Filho AKD, et al. Population-based seroprevalence of SARS-CoV-2 is more than halfway through the herd immunity threshold in the State of Maranhão, Brazil. medRxiv. 2020;20180463. https://doi.org/10.1101/2020.08.28.20180463

19. Secretaria Municipal de Saúde Campinas. I Inquérito soroepidemiológico Campinas - (COVID-19) [Internet]. 2020 [cited on Jul 06, 2020]. Available from: https://covid-19.campinas.sp.gov.br/pesquisas.

20. Bastos ML, Tavaziva G, Abidi SK, Campbell JR, Haraoui LP, Johnston JC, et al. Diagnostic accuracy of serological tests for covid-19: systematic review and meta-analysis. BMJ. 2020;370:m2516. https://doi.org/10.1136/bmj.m2516 